\title{
IN VITRO CLONAL PRODUCTION OF SALVADORA PERSICA PLANTLETS
}

\author{
HWIDA M. FATHY \\ Timber Trees Department, Horticulture Research Institute- ARC, Giza, Egypt
}

(Manuscript received 6 August 2017)

\begin{abstract}
$\mathrm{T}$ his work investigated mass production of plantlets from Salvadora persica (Meswak or tooth brush tree). For establishment stage three types of media (MS, WPM or B5), as well as two types of explants (shoot tip or nodal explant) were tested. For multiplication stage of subcultures and different combinations of BAP, KIN. and IBA were studied. Data showed that MS or WPM media gave significantly increased survival percentage comparing with B5 medium. Nodal explant recorded the greatest number of shootlets per explant. While, raising number of subcultures from one to three subcultures led to reducing the survival\% from ( 97.78 to 89.78 and $80.44 \%$ ) for two and three times of subcultures, respectively. However, the number of shootlets and leaves per explant were increased by increasing number of subcultures. A nonsignificant difference was found in shootlets length due to raising number of subcultures. The greatest results of root formation were occurred in the presence of activated charcoal and IBA. Rooted plantlets were transferred to greenhouse conditions after acclimatization with a success rate of $80 \%$.

Key words: Salvadora, in vitro, type of media, rooting.
\end{abstract}

\section{INTRODUCTION}

Salvadora persica Linn. (Meswak) is an evergreen small tree or shrub with a crooked trunk belongs to the family Salvadoraceae, used traditionally for the treatment of rheumatism, leprosy, gonorrhea, ulcer, scurvy, tumours, dental diseases, etc. (Almas and Zeid, 2004). Besides of, its medicinal potentialities, it is suitable in agroforestry systems as windbreak and helps in soil reclamation (Bhatia and Sharma 2000). This species tolerates frequent inundation by sea water, survives in intertidal and above tidal regions (Iyenger et al., 1992) and is drought and heat resistant tree of arid horticulture and forestry (Phulwaria, et al., 2011). Also, in many countries it is used as a fodder plant for cattle and goats (Rothauge, 2014). Salvadora persica is conventionally propagated through seed, however, seed viability is only about $30 \%$ (Mathur et al., 2008) and oil -rich seeds cannot be stored for longer periods besides, the seeds are infested with insects and pathogens. Also, this tree is a cross- pollinated species, therefore, the seeds do not produce true to the mother plant (Phulwaria et al., 2011). Additionally, very sparse reports are available on in vitro propagation of $S$. 
persica (Mathur et al., 2002). Therefore, methods for rapid in vitro micropropagation and genetic improvement are urgently warranted for this important plant species for its worldwide distribution and have been successfully employed for large scale multiplication of a number of woody plants.

Thus, the present study aims to find a suitable protocol to improve the different stages of in vitro propagation of $S$. persica for commercial production of this plant in Egypt through using different types of explant, media and hormones for initiation of mass production of this plant and reach to a suitable rooting stage. In addition to obtain a successful acclimatization of plantlets in green house.

\section{MATERIALS AND METHODS}

The experiments of this study were carried out at the Tissue Culture and Germplasm Conservation Research Laboratory, Horticulture Research Institute, Agricultural Research Center, Egypt, during the successive years 2014 to 2016.

\section{1-Explant source and surface disinfection.}

Explant material was selected from a Salvadora persica mother tree of about 15 years old, planted at the nursery of Timber Trees Dept., H.R.I., Agri. Res. Center,Giza, Egypt.

Shoot tips and nodal explants were used as sources of explants $(0.5-1.5) \mathrm{cm}$. Explants were surface disinfected under aseptic conditions by agitation in $70 \%$ ethanol for $2 \mathrm{~min}$. followed by $20 \%$ chlorox ( $\mathrm{NaOCl}, 2.5 \%$ active gradient) and a few drops of Tween -20 (polyoxyethylene sorbitan, as an emulsifier) for $5 \mathrm{~min}$., with respect to shoot tips explants, and for $7 \mathrm{~min}$. in for nodal explants. Further disinfection with mercuric chloride $\left(\mathrm{HgCl}_{2}\right)$ was applied at $0.1 \%$ for $2 \mathrm{~min}$.with shoot tips explants and 4min.for nodal explants.

Each disinfection process for all explants was followed by three sequential rinses by sterile distilled water.

\section{2-Culture establishment stage:}

In this experiment, two types of explants were used. Shoot tips with length of $(\sim 0.5-1.0 \mathrm{~cm}$.) and nodal explants $(\sim 10-15 \mathrm{~mm}$.) and cultured on three types of media, MS -basal medium (Murashige and Skoog,1962), WPM (Llyod and McCown ,1980) and B5 (Gamboreg,1986). The three media were supplemented with BA at $1 \mathrm{mg} / \mathrm{l}$ and IBA at $0.2 \mathrm{mg} / \mathrm{l}$. Cultured explants were incubated for 4 weeks under controlled conditions. Explant survival\%, shootlet length $(\mathrm{cm})$, number of shootlets and leaves per explant were investigated. 


\section{3- Shootlets multiplication stage:}

Shootlets originated from culture establishment were cultured on multiplication medium (which had the best results in establishment stage). MS-basal medium supplemented with $100 \mathrm{mg} / \mathrm{l}$ of casein hydrolysate, modified with fifteen different combinations of IBA at $(0.0,0.2$ and $0.5 \mathrm{mg} / \mathrm{l})$, BA and/or kinetin at $(0.0,0.5$ and $1.0 \mathrm{mg} / \mathrm{l})$ for both of them to induce shootlets multiplication. Cultures were subjected to three sequential subcultures with 4 weeks intervals. Shootlets survival\%, shootlet length, number of shootlets and leaves number per shootlet were considered.

\section{4- Shootlets rooting stage:}

Single shootlets produced from proliferation stage $(1-1.5) \mathrm{cm}$ long were separated and subjected to WPM medium supplemented with $100 \mathrm{mg} / \mathrm{l}$ casein hydrolysate in presence of activated charcoal $(2 \mathrm{~g} / \mathrm{l})$ or its absence. Four concentrations of either IBA or NAA at $(0.0,1.0,2.0$ and $3.0 \mathrm{mg} / \mathrm{l})$ were applied to investigate the capacity of rooting \% of shootlets, number of roots formed per shootlet and means of root length (cm).

During all stages, 5 replicates were considered, each replicate comprised 5 explants. Media employed in this investigation were supplemented with $25 \mathrm{~g} / \mathrm{l}$ sucrose. Medium $\mathrm{PH}$ was adjusted to $5.7 \pm 0.05$ and solidified with $0.7 \%$ agar. During establishment, multiplication and rooting stages, $25 \mathrm{ml}$ of medium were dispended into $200 \mathrm{ml} \mathrm{ca}$. glass jars and autoclaved for $20 \mathrm{~min}$. at $120^{\circ} \mathrm{C}$ and $1.2 \mathrm{Kg} / \mathrm{cm}^{3}$. Cultures were incubated in a growth chamber under $24^{\circ} \mathrm{C} \pm 2{ }^{\circ} \mathrm{C}$ and photoperiod $16 \mathrm{hrs} /$ day provided by 3 klux light intensity from $110 \mathrm{~cm}$ white fluorescent tube lamps (40 watts).

\section{5- Plantlets acclimatization:}

In the acclimatization stage, the shootlets which succeeded to produce roots resulting from different treatments were transferred to plastic pots ( 0.2 liter) containing peat moss plus washed sand at $1: 1(\mathrm{v} / \mathrm{v})$ as a growing media. The acclimatized plants were kept in greenhouse for six weeks then survival $\%$ of plants were recorded.

\section{Statistical analysis}

The averages of the experiments were statistically analyzed assuming a complete randomized design. A comparison among the means was done according to Duncan's multiple range test at $5 \%$ level of probability (Steel and Torrie,1980).

\section{RESULTS AND DISCUSSION}

\section{Culture establishment stage.}

Data presented in Table (1) revealed that, MS medium recorded the highest significant values of explant survival (70\%) and shootlets number (2.73) formed per 
explant and also the highest shootlet length $(1.60 \mathrm{~cm})$ comparing with the other media under investigation. However, the same characters recorded lower values $(43.33 \%, 1.20$ shootltes per explant and $0.67 \mathrm{~cm})$ respectively, when explants were cultured on B5 medium.

Concerning the effect of explant type, the results showed that, nodal explants give the highest significant values of survival (86.6\%) and shootlels number (2.95) per explant compared with shoot tip explant which recorded the lower significant values (33.33\% and 1.27 shootlet per explant).

Meanwhile the interaction between medium types and explant types, the data indicated that, nodal explant cultured on MS or WPM media induced the highest significant values of survival (100\% and $100 \%)$ respectively and shootlets number (3.67and 3.80) per explant, respectively comparing to B5 medium (1.40). But, there was no significant difference on shootlet length and leaves number as effected by three types of medium and the two explant types except, (B5 medium recorded lowest values for shootlets length).

The promoting effect of nodal explants and MS medium on survival\% and shootlets numbers per explant also was found by Mathur et al., (2008) on S. persica, Gad (2011) on Populus alba and Amin, Mona (2012) on Swietenia macrophylla . However, the difference between results on the three media can also be due to the interaction between ion uptake and endogenous hormones in plant, as explained by Eliane et al., (2007) .

Table 1. Effect of different medium types (MS, WPM or B5) and different explant types (shoot tip and nodal cutting) on explant survival\%, shootlets number, shootlet length $(\mathrm{cm})$ and leaves numbers per explant of Salvadora persica through establishment stage.

\begin{tabular}{|c|c|c|c|c|c|c|c|c|c|c|c|c|}
\hline \multirow{2}{*}{$\begin{array}{l}\text { Medium } \\
\text { types }\end{array}$} & \multicolumn{3}{|c|}{ Explant Survival \% } & \multicolumn{3}{|c|}{ Shootltes number } & \multicolumn{3}{|c|}{ Shootlet length $(\mathrm{cm})$} & \multicolumn{3}{|c|}{$\begin{array}{c}\text { Leaves } \\
\text { number/explant }\end{array}$} \\
\hline & $\begin{array}{l}\text { Shoot } \\
\text { Tip }\end{array}$ & $\begin{array}{l}\text { Nodal } \\
\text { cutting }\end{array}$ & $\begin{array}{l}\text { Mean } \\
\text { media }\end{array}$ & $\begin{array}{c}\text { Shoot } \\
\text { Tip }\end{array}$ & $\begin{array}{l}\text { Nodal } \\
\text { cutting } \\
\end{array}$ & $\begin{array}{l}\text { Mean } \\
\text { media }\end{array}$ & $\begin{array}{c}\text { Shoot } \\
\text { tip }\end{array}$ & $\begin{array}{l}\text { Nodal } \\
\text { cutting }\end{array}$ & $\begin{array}{l}\text { Mean } \\
\text { media } \\
\end{array}$ & $\begin{array}{c}\text { Shoot } \\
\text { tip }\end{array}$ & $\begin{array}{l}\text { Nodal } \\
\text { cutting }\end{array}$ & $\begin{array}{l}\text { Mean } \\
\text { media } \\
\end{array}$ \\
\hline MS & $40.0 \mathrm{bc}$ & $100 \mathrm{a}$ & $70.0 a$ & $1.80 \mathrm{~b}$ & $3.67 \mathrm{a}$ & $2.73 \mathrm{a}$ & $1.70 \mathrm{a}$ & $1.50 \mathrm{a}$ & $1.60 \mathrm{a}$ & $5.53 \mathrm{a}$ & $6.53 \mathrm{a}$ & $6.03 \mathrm{a}$ \\
\hline WPM & $33.30 \mathrm{c}$ & $100 \mathrm{a}$ & $66.67 \mathrm{a}$ & $1.00 \mathrm{~d}$ & $3.80 \mathrm{a}$ & $2.40 \mathrm{~b}$ & $1.53 \mathrm{a}$ & $1.53 \mathrm{a}$ & $1.53 \mathrm{a}$ & $5.20 \mathrm{a}$ & $6.90 \mathrm{a}$ & $6.05 \mathrm{a}$ \\
\hline B5 & $26.67 c$ & $60.0 \mathrm{~b}$ & $43.33 b$ & $1.00 \mathrm{~d}$ & $1.40 \mathrm{c}$ & $1.20 \mathrm{c}$ & $0.67 \mathrm{~b}$ & $0.57 \mathrm{~b}$ & $0.62 \mathrm{~b}$ & $4.87 \mathrm{a}$ & $4.87 \mathrm{a}$ & $4.87 \mathrm{a}$ \\
\hline $\begin{array}{c}\text { Means } \\
\text { Explant } \\
\text { type }\end{array}$ & 33.33B & 86.67A & & $1.27 \mathrm{~B}$ & $2.95 \mathrm{~A}$ & & $1.30 \mathrm{~A}$ & $1.20 \mathrm{~A}$ & & $5.20 \mathrm{~A}$ & $6.10 \mathrm{~A}$ & \\
\hline
\end{tabular}

*Digits followed by the same letter are not significantly different. 


\section{Multiplication stage.}

In this stage the explants were cultured on MS medium only, and subjected to the effect of various types and concentrations of growth regulators ( BAP, KIN and IBA) on shooting proliferation through three times of subculture to be investigated.

Data illustrated in Table (2) indicated that, raising the number of subculture from one to three times led to significant decrease in shootlets survival from 97.78 to $80.44 \%$. Supplemented multiplication medium with $\mathrm{KIN}$ at 0.5 or $1.0 \mathrm{mg} / \mathrm{l}$ in presence or absence of IBA recorded the highest significant values of survival $100 \%$, also providing the medium with BAP at $(0.5$ and $1.0 \mathrm{mg} / \mathrm{l})$ only or with $\mathrm{KIN}$ at $1.0 \mathrm{mg} / \mathrm{l}$ in presence of IBA at $0.2 \mathrm{mg} / \mathrm{l}$ recorded the same significant effect compared with control and other treatments. However, the lowest value of survival $(51.11 \%)$ was resulted from the supplement with $0.5 \mathrm{mg} / \mathrm{l}$ of BAP and IBA for each.

Concerning the interaction effect between the number of subculture and the different treatments of growth regulators, it was variable, however, the best results of survival $(100 \%)$ was due to the presence of KIN only or with IBA at the three times of subculture.

Shootlets numbers per explant was also affected by increasing the subculture number, it means that, as the number of subculture increased for three times the number of shootlets formed per explant raised significantly from the first and second subcultures $(3.70,5.38)$ to $(5.82)$ shootlets in the third subculture, respectively. Medium provided with BAP at $0.5 \mathrm{mg} / \mathrm{l}$ only or in presence of IBA at $0.2 \mathrm{mg} / \mathrm{l}$ recorded the highest significant mean values (8.74 and 8.21 ) shootlets /explant, respectively. In the same way the interaction between the numbers of subcultures and various growth regulators treatments resulted the highest number (10.33) of shootlets /explant, which was recorded after three subcultures on medium supplemented with BAP at $0.5 \mathrm{mg} / \mathrm{l}$ and IBP at $0.2 \mathrm{mg} / \mathrm{l}$ compared to (1.33) shootlets/explant with the control medium.

Phulwaria et al., (2011) who supporting results indicated that, repeated subculture of S. persica explant on the suitable proliferation medium raised the number of new produced shootlets/explant. Gad (2011) on Populus alba found that,the promoting effect of KIN at $0.2,0.4$ and BAP at $0.4 \mathrm{mg} / \mathrm{l}$ recorded the highest shootlet survival $(100 \%)$ in autumn season.

These results could be explained by that cytokinins have important physiological effects, as they have been shown to stimulate cell division as well as cell elongation, activate RNA synthesis, stimulate protein synthesis and enzyme activity, as was reviewed by Kulaeva (1980). Also, it is clear that the addition of BA to the medium increased shootlets production and enhanced them vigorously. The ability of 
explants to produce shoots was studied by Phulwaria et al., (2011) on Salvadar persica and Hashish et al.,(2015) on Hibiscus sinensis. They observed that multiple shoot induction was present in the stem explants that were cultured on MS medium provided with BA.

Table 2. Effect of subculture number and different concentration of (BAP, KIN and IBA) on shootlet survival\% and number of shootlets/ explant of Salvadora persica during multiplication stage.

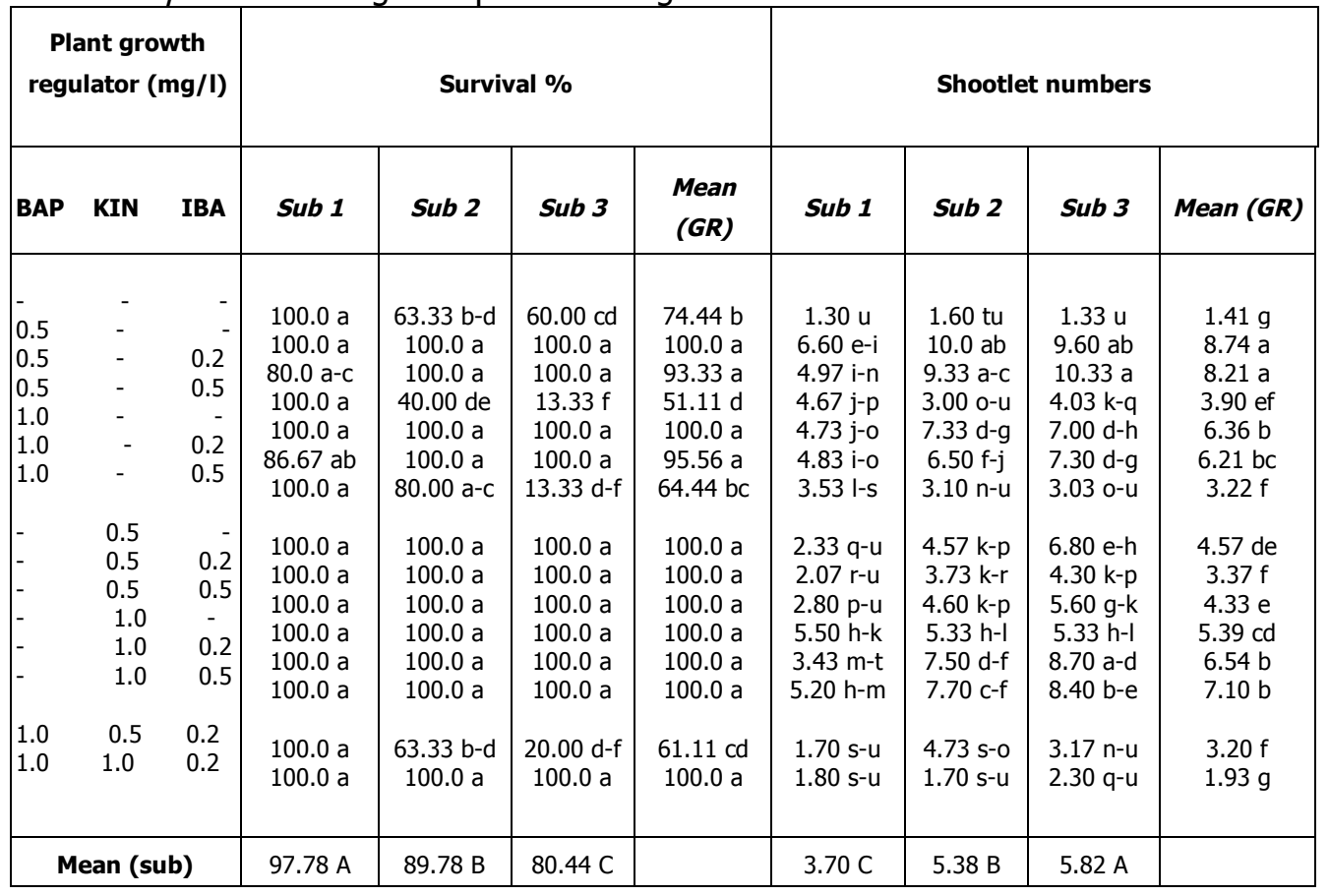

*Digits followed by the same letter are not significantly different.

**sub means subculture. GR means plant growth regulator.

Regarding the effect of the various growth regulators on shootlets length and number of leaves/ shootlet,it is illustrated in Table (3) that, increasing the number of subculture from one to three times had insignificant effect on the shootlets length. While the number of leaves/shootlet showed significant raise to 5.83 leaves at the third subculture compared to (5.13 and 5.02) leaves at the first and second subcultures. The highest significant value $(1.93 \mathrm{~cm})$ of shootlet length was recorded when the explants repeated cultured three subculture on the medium provided with kin at $1.0 \mathrm{mg} / \mathrm{l}$ in presence of IBA at $0.2 \mathrm{mg} / \mathrm{l}$.

However, increased the concentration of KIN to $1.0 \mathrm{mg} / \mathrm{l}$ plus IBA at $0.5 \mathrm{mg} / \mathrm{l}$ showed the highest values of leaves number (8.33, 9.0 and 9.0) leaves /shootlet through the sequent three subcultures. On the other hand, the addition of BAP in all concentrations had no positive influence on either shootlets length or number of leaves/shootlet compared with the control and the various treatment of KIN. 
Hence, KIN was more positive in affecting on shootlets length and leaves number than BAP of Salvadra persica grown in vitro. Also, Phulawira, et al., (2011) found the same trend, in addition to Parra and Amo-Marco (1998) who mentioned that the enhancing effect of endogenous hormonal balance to promote the cell reflected on differentiation into more vegetative growth which can be induced by exogenous supplementation of plant growth regulators to culture medium of Myrtus commuins plants.

Table 3. Effect of subculture number and different concentrations of (BAP, KIN and IBA) on shootlet length $(\mathrm{cm})$ and number of leaves/ shootlet of Salvadora persica during multiplication stage .

\begin{tabular}{|c|c|c|c|c|c|c|c|c|c|c|}
\hline \multicolumn{3}{|c|}{$\begin{array}{c}\text { Plant growth } \\
\text { regulators }(\mathrm{mg} / \mathrm{l})\end{array}$} & \multicolumn{4}{|c|}{ Shootlet length $(\mathrm{cm})$} & \multicolumn{4}{|c|}{ Leaves number/shootlet } \\
\hline BAP & KIN & IBA & Sub 1 & Sub 2 & Sub 3 & Mean (GR) & Sub 1 & Sub2 & Sub 3 & Mean (GR) \\
\hline- & - & - & $1.22 \mathrm{c}-\mathrm{g}$ & $0.82 \mathrm{~g}-0$ & $0.97 \mathrm{~d}-\mathrm{I}$ & $1.00 \mathrm{~b}-\mathrm{d}$ & $7.07 \mathrm{~b}-\mathrm{d}$ & $5.90 c-g$ & $5.17 \mathrm{e}-\mathrm{h}$ & $6.04 b c$ \\
\hline 0.5 & - & - & $0.68 \mathrm{j}-0$ & $0.83 g-0$ & $0.78 \mathrm{~g}-0$ & $0.77 \mathrm{de}$ & $4.33 \mathrm{f}-\mathrm{k}$ & 5.00 e-h & 5.20 e-h & $4.84 \mathrm{de}$ \\
\hline 0.5 & - & 0.2 & $0.57 \mathrm{k}-0$ & $0.50 \mathrm{I}-0$ & 0.73 h-o & 0.60 ef & $3.17 \mathrm{i}-\mathrm{I}$ & $4.15 \mathrm{~g}-\mathrm{k}$ & $4.50 \mathrm{f}-\mathrm{j}$ & 3.94 ef \\
\hline 0.5 & - & 0.5 & 0.45 no & 0.400 & 0.42 no & $0.42 \mathrm{f}$ & $4.67 \mathrm{f}-\mathrm{j}$ & $2.67 \mathrm{kl}$ & $3.00 \mathrm{j}-1$ & $3.44 \mathrm{f}$ \\
\hline 1.0 & - & & $0.50 \mathrm{l}-0$ & 0.43 no & $0.80 \mathrm{~g}-0$ & 0.58 ef & $3.00 \mathrm{j}-1$ & $3.53 \mathrm{~h}-\mathrm{I}$ & 5.20 e-h & $3.91 \mathrm{ef}$ \\
\hline 1.0 & - & 0.2 & $0.57 \mathrm{k}-0$ & $0.48 \mathrm{mo}$ & $0.75 g-0$ & 0.60 ef & $4.17 \mathrm{~g}-\mathrm{k}$ & $3.00 \mathrm{j}-1$ & $6.00 \mathrm{c}-\mathrm{f}$ & $4.39 \mathrm{e}$ \\
\hline 1.0 & - & 0.5 & $0.83 \mathrm{~g}-0$ & $0.57 \mathrm{k}-0$ & 0.47 no & 0.62 ef & $4.80 \mathrm{f}-\mathrm{i}$ & 2.331 & $3.00 \mathrm{j}-1$ & $3.38 \mathrm{f}$ \\
\hline- & 0.5 & - & $1.00 \mathrm{~d}-\mathrm{k}$ & $1.18 \mathrm{c}-\mathrm{h}$ & $1.33 c-f$ & $1.17 \mathrm{~b}$ & $5.03 e-h$ & 6.67 b-e & $7.33 \mathrm{bc}$ & $6.34 b c$ \\
\hline- & 0.5 & 0.2 & $1.20 \mathrm{c}-\mathrm{h}$ & $1.11 c-s$ & $1.07 c-j$ & $1.12 \mathrm{~b}$ & 5.00 e-h & $5.33 \mathrm{~d}-\mathrm{h}$ & $7.00 \mathrm{~b}-\mathrm{d}$ & $5.78 b c$ \\
\hline- & 0.5 & 0.5 & $1.17 c-j$ & $1.02 c-k$ & $0.95 \mathrm{e}-\mathrm{m}$ & $1.04 b c$ & 6.67 b-e & $5.87 \mathrm{c}-\mathrm{g}$ & $7.00 \mathrm{~b}-\mathrm{d}$ & $6.51 b$ \\
\hline- & 1.0 & - & $1.47 b c$ & $0.75 \mathrm{~g}-0$ & $0.80 \mathrm{~g}-0$ & 1.01 b-d & $6.10 c-f$ & $4.00 \mathrm{~h}-\mathrm{I}$ & $3.67 \mathrm{~h}-\mathrm{I}$ & $4.60 \mathrm{de}$ \\
\hline- & 1.0 & 0.2 & $0.78 \mathrm{~g}-0$ & $1.85 a b$ & $1.93 \mathrm{a}$ & $1.52 \mathrm{a}$ & $5.33 \mathrm{~d}-\mathrm{h}$ & $7.33 b-c$ & $7.33 \mathrm{bc}$ & $6.67 b$ \\
\hline- & 1.0 & 0.5 & $1.83 a b$ & $1.37 \mathrm{c}-\mathrm{k}$ & $1.42 \mathrm{~cd}$ & $1.54 \mathrm{a}$ & $8.33 a b$ & $9.00 \mathrm{a}$ & $9.00 \mathrm{a}$ & $8.78 \mathrm{a}$ \\
\hline 1.0 & 0.5 & 0.2 & $0.70 \mathrm{i}-0$ & $0.83 \mathrm{~g}-0$ & $0.88 \mathrm{f}-\mathrm{n}$ & $0.81 \mathrm{c}-\mathrm{e}$ & $4.54 \mathrm{f}-\mathrm{j}$ & $4.67 \mathrm{f}-\mathrm{j}$ & $7.00 \mathrm{~b}-\mathrm{d}$ & $5.40 \mathrm{~cd}$ \\
\hline 1.0 & 1.0 & 0.2 & 0.73 h-o & $1.08 c-j$ & 1.40 c-e & $1.07 \mathrm{~b}$ & $4.67 \mathrm{f}-\mathrm{j}$ & $5.87 \mathrm{c}-\mathrm{g}$ & $7.00 \mathrm{~b}-\mathrm{d}$ & $5.48 \mathrm{bc}$ \\
\hline \multicolumn{3}{|c|}{ Mean (sub) } & $0.91 \mathrm{~A}$ & $0.88 \mathrm{~A}$ & $0.98 \mathrm{~A}$ & & $5.13 \mathrm{~B}$ & $5.02 \mathrm{~B}$ & $5.83 \mathrm{~A}$ & \\
\hline
\end{tabular}

*Digits followed by the same letter are not significantly different.

\section{Rooting stage}

In this stage the effect of providing rooting medium with Activated Charcoal (AC) at $(0.0$ and $2 \mathrm{~g} / \mathrm{l})$ and different concentrations of IBA or NAA on rooting behavior of shootlets was tested.

Data presented in Figs $(1 a, b, c,, 2 a, b, c$ and $3 a, b, c)$ revealed that, the highest significant values of rooting percent (15.24\%), number of root formed per, shootlet $(0.81)$ and longest mean of root $(6.95 \mathrm{~cm})$ was markedly noticed when shootlets were cultured on rooting medium was supplemented by $\mathrm{AC}(2 \mathrm{~g} / \mathrm{l})$. 
Also, providing the medium with IBA at 2.0 or $3.0 \mathrm{mg} / \mathrm{l}$ recorded the highest significant values (23.66 and $26.67 \%$ ) of rooting, (1.0 and 1.5 ) roots/shootlet and longest roots (10.33 and 11.17$) \mathrm{cm}$, respectively for shootlets compared with the different concentrations of NAA or control treatment.

In the same trend, the interaction between the presence or absence of $A C$ and different rooting growth regulators (auxins), data reveal that, the highest significant values of rooting $\%$, number of root /shootlet and the longest root $(40.0 \%$ , $2.33 \mathrm{root} / \mathrm{shootlet}$ and $17.33 \mathrm{~cm}$ ) respectively, occurred when the rooting medium was supplemented with $2 \mathrm{~g} / \mathrm{l}$ AC combined with $3 \mathrm{mg} / \mathrm{l}$ IBA.

In contrast, supplementing the rooting medium with NAA recorded insignificant effect on rooting behavior of shootlets although it raised the rooting percent to $(6.67 \%)$, number of root/shootlet to $(0.33)$ and the length of root ranged between $(1.67$ and $2.67 \mathrm{~cm})$ in the presence of AC only at the three concentration of NAA, compared with control .

These results are in harmony with those reported by Hanafy, et al. (2002) on Myrtus communis, Phulwaria, et al . (2011) on Meswak, they found that increasing the concentration of both IBA or NAA mostly enhanced root initiation and elongation. Also, the promoting effect of activated charcoal on rooting behavior was found by Somika, et al.,(2002) on Morus indica , Gad et al., (2006)on Sequoia sempervirens ,Gad (2011) on Populus alba and Sami, et al., (2016) on Hibiscus syriacus. They stated that, the positive affect of $A C$ on morphogenesis may be due to, irreversible adsorption of inhibitory or toxic compounds, darkening and aeration of culture medium and gradual release of substances naturally present in $A C$ or adsorbed products which promote growth, so they become available to plants.

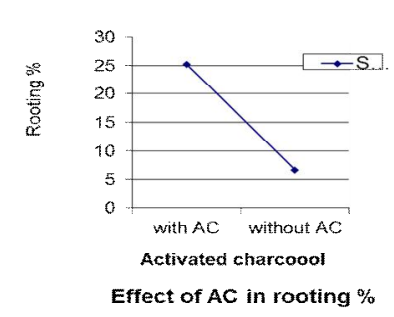

( Fig.1a)

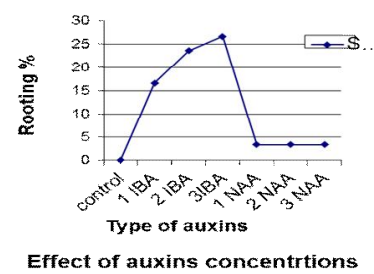

(Fig.1b)

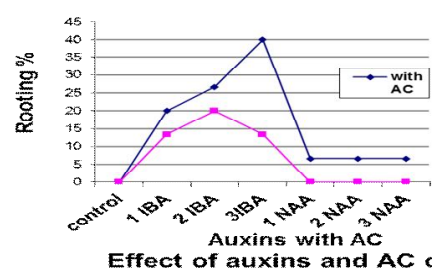

(Fig.1c)

Fig. (1) a, b and c : Effect of activated charcoal and different concentration of auxins on rooting\% of $S$. persica plant. 


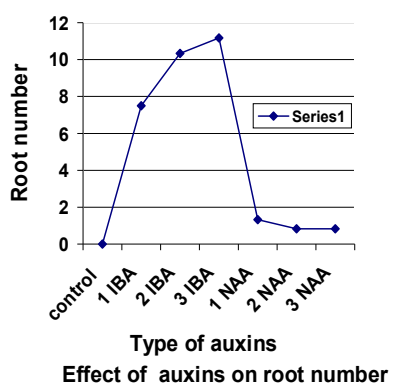

(Fig2a )

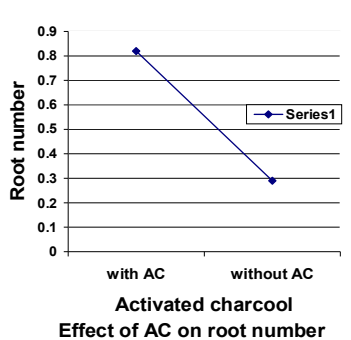

(Fig 2b)

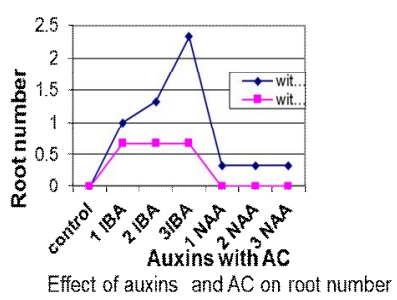

(Fig 2c)

Fig (2) a,b and c: Effect of activated charcoal and different concentration of auxins on roots number of $S$. persica plant.

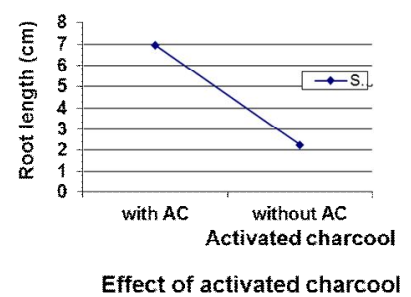

(Fig 3a)

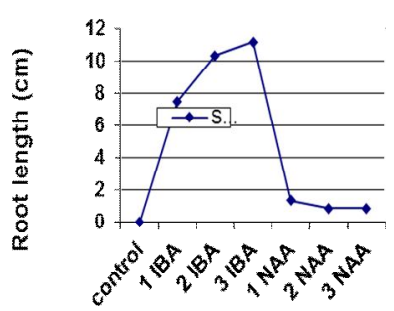

Auxins concentrations

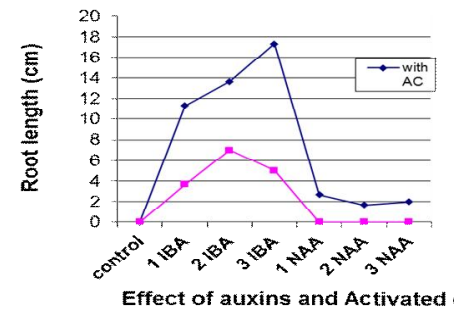

( Fig3c)

Fig. ( 3) a,b and c: Effect of activated charcoal and different concentration of auxins on root length $(\mathrm{cm})$ of $S$. persica plant.

\section{Acclimatization stage.}

Shootlets acclimatization is the final stage and its success controls the success of the whole work. Figs. (4 and 5) showed that, shootlets succeded to produce roots in the rooting stage from different treatments were transferred to plastic pots ( 0.2 liter) containing peat moss plus washed sand at $1: 1(\mathrm{v} / \mathrm{v})$ as growing medium. The acclimatized plants were kept in the greenhouse for six weeks after that the survival of plants was recorded ( $80 \%)$.

It could be concluded that the acclimatization mixture including peat moss and sand with a ratio of (1:1) might had enhancing effect on its physical and chemical characters, consequently improved acclimatized shoots and roots growth characters. Peat moss has both high water and nutrient holding characteristics, while the sand has high penetrating effect and good aeration for roots (Taha, et al. 2008 and Gad 2011). 


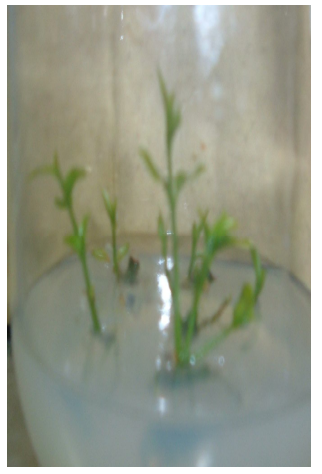

(

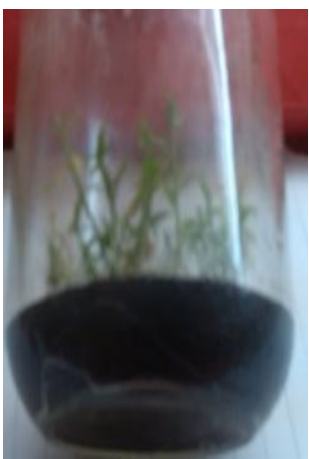

( II)

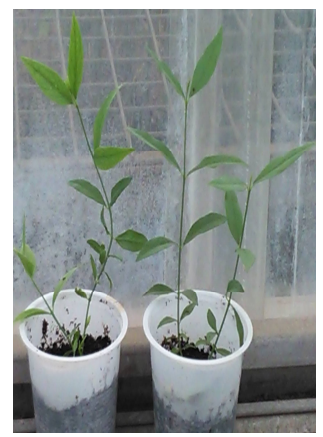

Fig ( 4)

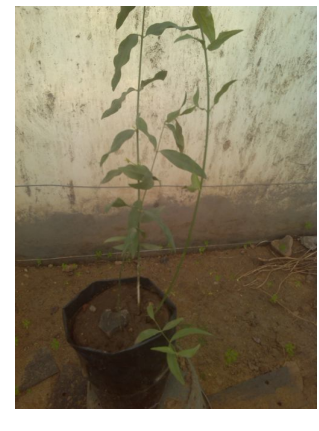

Fig (5)

$(I)=$ S. persica on multiplication stage. $\quad(I I)=$ S. persica on rooting stage. Fig (4) : plantlets of $\boldsymbol{S}$. persica after three months of acclimatization stage. Fig (5) : plantlets of $\boldsymbol{S}$. persica after one year.

\section{CONCLUSION}

Finally, the present work confirmed that we can obtain the greatest number of shootlets of $S$. perisca with high survival \% when culture explant on MS medium provided with BAP at $0.5 \mathrm{mg} / \mathrm{l}$ and IBA at $0.2 \mathrm{mg} / \mathrm{l}$ after three times of subculture. Charcoal was a good promoter to induce roots formation in presence of IBA at 3.0 $\mathrm{mg} / \mathrm{l}$.

\section{REFERENCES}

1. Almas, K. and Z., Zeid. 2004. The immediate antimicrobial effect of toothbrush and miswak on cariogenic bacteria: a clinical study.J. Contemp.Dent. Pract.,5(1):105- 114.

2. Bhatia, B. and H.L. Sharma. 2000. Fuel wood Production and Waste land Reclamation. Botanica , $50,84-93$.

3. Eliane ,D.;N.K. Antonio;L.Z., Anderson;K.I.,Henrique and I., Ribas. 2007. In vitro multiplication of Swietenia macrophylla from juvenil shoots, J. Sci.Vol. (17):2, 109117.

4. Gad, Mervat M.A. 2011. Clonal propagation and mass production of Populus alba mother-plus tree through tissue culture techniques. J.of Appl.Sci.,26(12B):390-416.

5. Gad, Mervat M.A.;M.A.,Salem and Hwida, M.F. El-Sayed. 2006. Clonal propagation of Sequoia sempervirens, D.Don, Endl.through tissue culture techniques. Proceedings of First International Conference on: Strategy of Botanic Gardens. Bull.of CAIMHerbarium, Vol.7,:53-69.

6. Gamborg, O.L. 1986. Cells,Protoplasts and Plant Regeneration in Culture.In:Manual of Industrial Microbiolgy and Biotechnology.A.L.Demain and N.A.Solomon, editors, Dept.of Nutrition andFood Science,Mass.Inst.of Tech.,Cambridge,Mass. 
7. Hanafy,A.H.; Mervat .A.Gad;H.M. Hassan,and Mona A.Amin(2002). In vitro mass production of Myrtus communis and factors affecting its acclimatization.Proc. Minia1st Conf. for Agric. \& Environ. Sci., Minia, Egypt,Vol.(C):1721-1744.

8. Hashish, KH. I.; Taha, Lobna, S. and Soad, M. M., Ibrahim. 2015. Micropropagation potentiality and pigments content of Hibiscus rosa-sinensis L.as affected by gamma radiation. Int.J.of ChemTech Res.,Vol.8,No.9,pp 131-136.

9. Iyenger, E.R.R.; J. S. Patiolia and J. Chikara. 1992. A useful plant for coastal saline soils. Wastelands New 32:50-51(August-October issue).

10. Kulaeva, O.N. 1980. In: Skoog, F. (ed.). Springer-Verlag. Berlin, Heidelberg, New York, pp: 119-128.

11. Llyod,G. and B., McCown. 1980. Commercially feasible micropropagation of mountain loure, Kalmia latifolia ,by using of shoot tip culture .Comb.Proceed. Int. Plant Prop.Soc ., 30:421-427.

12. Mathur S.;G.S.,Shekhawat and A., Batra. 2002. Micropropagation of Salvadora persica via cotyeldonary nodes. Indian J. Biotechnol,1:197-200.

13. Mathur,S.;G.S.Shekhawat and A., Batra. 2008. Somatic emberyogensis from cotyledon explant of Salvadora persica L. Phytomorphol,58(1-2):57-63.

14. Amin, Mona A. 2012. In vitro propagation of Swietenia macrophylla King .Agri.and Biol. Sci.,8(2):282-287.

15. Murashige,T. and F., Skoog, 1962. A revised medium for rapid growth and bioassays with tobacco tissue cultures.Physiol.Plant,15:473-497.

16. Parra,R. and J.B., Amo-Marco. 1998. Factors affecting In vitro shoot proliferation of Myrtus communis/L,A comparion of adult and seedling material.In vitro cellular and Development Biology Biologia Plantrarum,34(2):104-107.

17. Phulwaria,M; R., Kheta; G.Priyanka and N.S.Shekhawat. 2011. Micropropagation of Salvadora persica -a tree of arid horticulture and forestry. New Forests ,42:317-327.

18. .Rothauge,A., 2014. Staying afloat during a drought. The Namibian News, Agri.Cult. 25 of Feb.

19. Sami,A. Metwally ; Kh.I.Hashish ; Sawsan, S. Sayed; Lobna, S. Taha 2016. In vitro propagation protocol of Hibiscus syriacus L. plants.Inter.J.of Pharm Tech Res.Vol.9 No.11,pp 178-186.

20. Somika,B.; D.Manaswini; K.H.Paramjit; S.Bhatnagar; M.Dos and P.Khurana. 2002. Rapid in vitro TDZ-mediated micropropagation of Morus indica C176 and C776 through axillary buds.Ind.J.Seiculture,41(1): 80-83.

21. Steel, R.G.D. and S. H. Torrie. 1980. Principle of Statistics. A biometrical Approach Second Ed.,McGraw-Hill,U.S.A.

22. Taha, S. Lobna; M.M. Soad Ibrahim and M.M., Farahat. 2008. A Micropropagation Protocol of Paulownia kowakamii through in vitro culture technique. Australian Journal of Basic and Applied Sciences, 2(3): 594-600. 


\title{
الاكثار الخضري لنبات السو(الك من خلال تكنيك زراعة الآسجة
}

\author{
هويدا محمد فتحى \\ قسم بحوث الاشجار الخشبيه - معهُ بحوث البساتين - مركز البحوث الزراعيه
}

أجريت هذه الدراسة لتحديد افضل طريقه للاتتاج المكثف لنبات السوا(ك من خلا تكنيك زراعة الاسجه : في المرحلة الابتدائية استخدمت ثلاث أنو اع من البيئات الغذائية وهى بيئة مورشيجى وسكوج

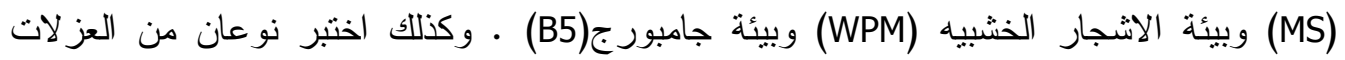

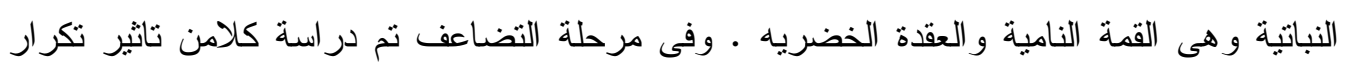

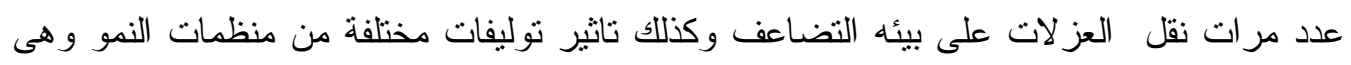
البنزيل امينو بيورين - الكينتين - و اندول حامض البيوتيريك. وقد أوضحت النتائج انه باستخدام بيئات ( MS و MPM) قد أعطت افضل قدرة لبقاء النباتات حيه مقارنة ببيئة (B5). كما أظهرت النتائج انه باستخدام العقد الخضريه أعطت اكثر عدد من الافرع النباتية المتكونة لكل عزله لهنه نباتية

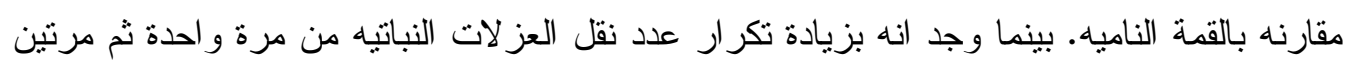
ثم ثلات مر ات قد أدى ذلك الى انخفاض نسبة بقاء النباتات حيه من.

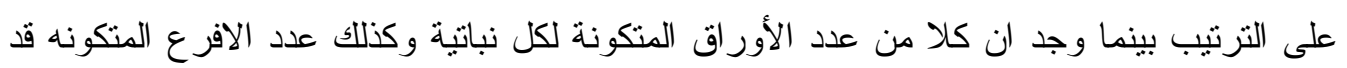

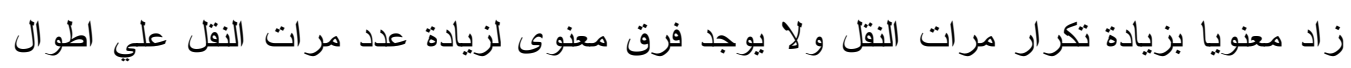

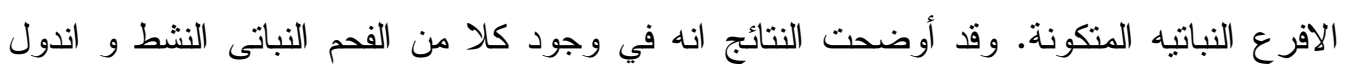

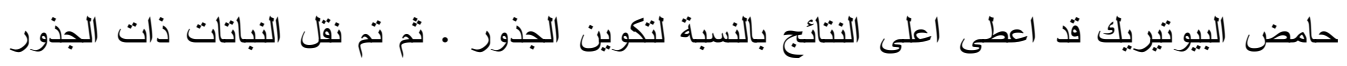

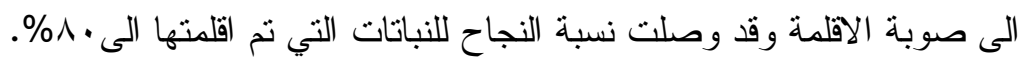

